\title{
MŮJ ŽÁK, UČITEL A PŘíTEL PETR SVOBODNÝ
}

Profesní dráhu jubilanta Petra Svobodného si může dnes, ve světě digitálních medií, každý najít na internetu, proto zde jen velmi stručně. Pražský rodák (20. 3. 1958), absolvent prestižního akademického gymnázia, vystudoval na Filozofické fakultě Univerzity Karlovy obor historie a v roce 1981 nastoupil do Okresního muzea v Jílovém u Prahy. V říjnu roku 1985 získal místo v Ústavu dějin lékařství tehdy Fakulty všeobecného lékařství - dnes 1. lékařské fakulty UK. Na počátku roku 1990 odešel do Archivu Univerzity Karlovy (dnes Ústav dějin UK a archiv UK), v jehož čele stojí od roku 2005 jako ředitel. V roce 2000 se habilitoval pro obor moderní dějiny, profesorem dějin lékařství byl jmenován v roce 2014. Věnuje se i přednáškové činnosti na Filozofické fakultě UK, Fakultě sociálních věd UK a 1. lékařské fakultě UK. V různých funkcích pracuje v redakčních radách (mj. je předsedou redakční rady AUC-HUCP) a vědeckých kolegiích doma i v zahraničí (například je předsedou Společnosti pro dějiny vědy a techniky).

Pamatuji se velmi živě na to, jak přišel poprvé jako nový pracovník do našeho ústavu, tehdy umístěného ve velmi stísněných prostorách v přizemí budovy děkanátu FVL UK v Kateřinské ulici. Zazvonil na dveře našeho knihovního depozitáře, kde byly dva stoly pro pracovníky ústavu - u jednoho jsem od roku 1961 seděla já, druhé bylo určeno jemu. Když jsem otevřela, spatřila jsem převysokého mladíka, který se velmi zdvořile představil; působil na mne vážným, až poněkud smutným dojmem. Brzy se ukázalo, že tento první dojem byl mylný. Užili jsme si s ním i hodně legrace.

Tehdy jsme zpracovávali dějiny biologického ústavu k jeho jubileu a Petr naskočil tak říkajíc do rozjetého vlaku. Bylo potřeba zpracovat toto téma od nejstarších dob. Já se celý svůj profesní život důsledně vyhýbám středověké historii, abych unikla přísné kritice ze strany svého medievistického manžela. Když jsem Petra požádala, aby se tohoto úkolu ujal, splnil ho velmi rychle a dobře. Tím byla zahájena naše spolupráce, která dnes již trvá 35 let. V řadě př́ipadů se ujal v našich společných publikacích zpracování období, do kterých se mi nechtělo - vedle středověku i období novověku a laskavě mi ponechával mé oblíbené 18. a 19. století. Tak tomu bylo i ve velkých univerzitních dějinách, v dějinách všeobecné nemocnice, $v$ dějinách lékařství v našich zemích aj.

Občas bývá Petr vzhledem k našemu věkovému rozdílu nazýván mým žákem. Já ho ovšem takto nevnímám. Od počátku byl mým pracovně naprosto rovnocenným partnerem, a vedle toho i shovívavým učitelem, který opravuje v našich společných publikacích mé špatně používané čárky, nesprávné pořadí v citování ročníků a let u časopisů apod.

Obdivuji jeho pracovní tempo. Občas jsem byla zpočátku znepokojena, zda dodá svůj díl do společné publikace včas. Brzy po sametové revoluci jsme třeba dostali úkol napsat skripta o dějinách pražských lékařských fakult. Petr byl tehdy na stáži v Německu, emailové spojení ještě neexistovalo, byla jsem trochu nervózní, jak to dopadne. Samozřejmě dobře, termín jsme dodrželi. A tak tomu bylo při všech našich společných publikacích. 
Naše pracovní přátelství je utuženo i přátelstvím tak ř́kajíc rodinným. Svět je malý a brzy vyšlo najevo, že v dětství jsem kamarádila s Petrovou maminkou, protože bydlela v sousedním domě. Poté se odstěhovala a zmizela mi z dohledu. Přátelství bylo obnoveno, když Petr přišel do našeho ústavu. Obdivuji Petra i proto, že si na rozdíl od mnoha svých kolegů vždy našel a nachází čas pro svoji rodinu, manželku Evu a tři milé a úspěšné dcery, s nimiž sdílí zálibu např́klad v aktivně provozovaném orientačním běhu. Pouze jeho lezení po komínech, v němž nalezl zalíbení v posledních letech, mi dělá trochu starost.

Milý „Petrik“! Spolupráci a přátelství s Tebou považuji za opravdovou př́zeň svého osudu. Doufám, že mi tento dopřeje ještě s Tebou něco společně napsat, abys mi opravil ty čárky a citace. 